\title{
THE EFFECTS OF TOPDRESSING DAIRY PASTURES IN THE WAIKATO WITH SODIUM CHLORIDE
}

MB. O'Connor', B. Addison' and AD. Miller ${ }^{2}$ ${ }^{1}$ MAFTech, Ruakura Agricultural Centre, Hamilton ${ }^{2}$ Dominion Salt Ltd, Blenheim

\begin{abstract}
Recent dairy farm survey data suggest the sodium $(\mathrm{Na}$ ) concentration in pastures could be too low to maintain stock health on a number of farms. Trials have been established on three major soil groups in the Waikato to study: (a) the rates of $\mathrm{NaCl}$ rauired to raise $\mathrm{Na}$ concentrations in pasture; (b) the time required to do this; (c) the duration of the response; and (d) the effect of $\mathrm{KCl}$ on $\mathrm{Na}$ uptake. $\mathrm{Na}$ uptake in pasture was rapid initially, reaching a peak some 6 weeks after application. Thereafter the $\mathrm{Na}$ concentration in pasture declined gradually but after 30 weeks was still some 2 to 3 times the initial $\mathrm{Na}$ concentration. Soil $\mathrm{Na}$ levels followed a similar trend.

Conclusions to date suggest an annual topdressing of $\mathrm{NaCl}$ at $100 \mathrm{~kg} / \mathrm{ha}$ will provide an adequate $\mathrm{Na}$ concentration in the pasture for animal health and production on a range of Waikato soils. In practice salt can be applied alone or mixed with other fertilisers. Where potassium is already high some replacement of $\mathrm{NaCl}$ for $\mathrm{KCl}$ in the fertiliser mixture can be considered. Regular monitoring by pasture analysis is recommended. Although salt applications will increase the $\mathrm{Na}$ content in the pasture, animal responses to $\mathrm{Na}$ supplementation have yet to be conclusively demonstrated. Research is planned with dairy cows in the Waikato to investigate this important aspect.
\end{abstract}

Keywords: Salt, sodium chloride, pasture sodium, ryegrass, white clover pastures, topdressing, dairy cows

\section{INTRODUCTION}

The importance of salt $(\mathrm{NaCl})$ in the diet of grazing animals has been recognised for many years. Reference to the use of salt for cattle can be found as early as 150 BC. A response in milk production of dairy cattle given a salt supplement was shown by Babcock (1905). Later work (Aines \& Smith 1957) showed sodium $(\mathrm{Na})$ rather than chlorine to be the cause of the milk production response.

Direct supplementation of salt to animals is probably the most effective method of correcting a deficiency, but the use of salt as a fertiliser is an alternative method. It relies on being able to increase $\mathrm{Na}$ concentration in the leaves of pasture plants. Estimates of adequate or deficient $\mathrm{Na}$ concentrations in mixed pasture needed to maintain health and production are shown in Table 1 (Towers \& Smith 1983).

Table 1: Estimates of pasture $\mathrm{Na}$ concentrations required to maintain stock health and production

\begin{tabular}{lcc}
\hline & & \% Na on DM basis \\
& Adequate & Deficient \\
\hline Lambs & 0.07 & 0.04 \\
Ewes (lactating) & 0.09 & 0.05 \\
Cattle & 0.10 & 0.06 \\
Dairy cows (lactating) & 0.12 & 0.09 \\
\hline
\end{tabular}

A recent survey of 312 North Island dairy farms (Carruthers et al. 1987) indicated that pasture on $19 \%$ of Taranaki farms, $38 \%$ of Bay of Plenty farms and $22 \%$ of Waikato farms was deficient in $\mathrm{Na}$ (below $0.10 \% \mathrm{Na}$ ). In September 1987 
three field trials were begun in the Waikato to determine rates of $\mathrm{NaCl}$ required to increase $\mathrm{Na}$ concentrations in pasture, the time to do this, the duration of the effect and the influence of added $\mathrm{K}$ on the increase in $\mathrm{Na}$ concentration. The results of the first 30 weeks of the study are reported.

\section{METHODS}

Three trial sites were chosen on the basis of low pasture $\mathrm{Na}$ levels $(<0.10 \% \mathrm{Na})$. All were on dairying pastures and included a yellow-brown pumice soil $10 \mathrm{~km}$ south of Putaruru (site 1); a yellow-brown loam $4 \mathrm{~km}$ west of Tirau (site 2); and a peat soil 8 $\mathrm{km}$ south-west of Cambridge (site 3). At each site 5 rates of $\mathrm{NaCl}(0,50,100,200$ and $400 \mathrm{~kg} / \mathrm{ha}$ ) and 2 rates of $\mathrm{KCl}(0$ and $140 \mathrm{~kg} / \mathrm{ha}$ ) were applied in a split-plot design with rates of $\mathrm{KCl}$ as main treatments and rates of $\mathrm{NaCl}$ as sub treatments. Plot size was $5 \times 2 \mathrm{~m}$. The trials began in September 1987 and were operated under a 'mowing and clippings return' technique with approximately $35 \%$ of the clippings returned to each plot.

Measurements included pasture dry matter (DM) determinations on 8 cuts September 1987 to March 1988; K and $\mathrm{Na}$ determinations on pasture samples taken at $0,6,12,20$ and 30 weeks; MAF Soil Quick Tests for $\mathrm{pH}, \mathrm{Ca}, \mathrm{P}, \mathrm{K}, \mathrm{Mg}, \mathrm{Na}$ on soil samples $(\mathrm{O}-8 \mathrm{~cm})$ taken at similar intervals together with deep soil sampling (815 and $16-30 \mathrm{~cm}$ ) on the control and $400 \mathrm{NaCl}, 140 \mathrm{KCl}$ treatments only.

Rainfall was measured at each site and the $\mathrm{Na}$ concentration of the rainwater determined.

\section{Pasture production}

Pasture production measured over 30 weeks totalled $10.3,8.9$ and $8.0 \mathrm{t} / \mathrm{ha} \mathrm{DM}$ at sites 1,2 and 3 respectively. $\mathrm{NaCl}$ had no effect on pasture production at sites 1 and 2 but for the first 4 months on site 3 pasture production was depressed by approximately 20\%. There was no apparent reason for this initial depression. Pasture burning was not evident.

\section{Sodium in pasture}

The $\mathrm{Na}$ content in the pasture increased on all sites after $\mathrm{NaCl}$ application, reaching a peak after 6 weeks (Table 2). Thereafter the $\mathrm{Na}$ concentrations gradually declined on sites 1 and 3 but remained remarkably constant on site 2 (yellow-brown loam) up to 30 weeks after application. There was a strong linear relationship on all sites between $\mathrm{Na}$ content in pasture and rate of $\mathrm{NaCl}$ applied $(r=0.99)$.

On sites 1 and 2, $100 \mathrm{~kg} \mathrm{NaCl} /$ ha increased $\mathrm{Na}$ in pasture above $0.2 \% \mathrm{Na}$; on

Table 2: Effect of applied $\mathrm{NaCl}$ on the Na contentof pasture on 3 soils

\begin{tabular}{|c|c|c|c|c|c|c|c|c|c|c|c|c|}
\hline $\begin{array}{l}\mathrm{KgNaCl} / \text { ha } \\
\text { Soilgroup }\end{array}$ & YBP' & $\begin{array}{l}50 \\
Y B L^{2}\end{array}$ & Peat & YBP & $\begin{array}{l}100 \\
\text { YBL } \\
\% \mathrm{Na}\end{array}$ & $\begin{array}{l}\text { Peat } \\
\text { on DM }\end{array}$ & $\begin{array}{l}\text { YBP } \\
\text { basis }\end{array}$ & $\begin{array}{l}200 \\
\text { YBL }\end{array}$ & Peat & YBP & $\begin{array}{l}400 \\
\text { YBL }\end{array}$ & Peat \\
\hline $\begin{array}{l}\text { At start } \\
\text { (Sept '67) }\end{array}$ & 0.07 & 0.12 & 0.06 & 0.07 & 0.12 & 0.06 & 0.07 & 0.12 & 0.06 & 0.07 & 0.12 & 0.06 \\
\hline $\begin{array}{l}6 \text { weeks } \\
\text { (Oct ' } 67 \text { ) }\end{array}$ & 0.15 & 0.21 & 0.12 & 0.23 & 0.22 & 0.14 & 0.24 & 027 & 0.23 & 0.34 & 0.39 & 0.28 \\
\hline $\begin{array}{l}30 \text { weeks } \\
(\text { March ' } 88 \text { ) }\end{array}$ & 0.11 & 0.17 & 0.13 & 0.15 & 0.23 & 0.17 & 0.16 & 0.31 & 0.16 & 0.21 & 0.34 & 0.21 \\
\hline
\end{tabular}

Yellow-brown pumice

2 Yellow-brown loam 
site $3,200 \mathrm{~kg} \mathrm{NaCl} / \mathrm{ha}$ was required to achieve a similar increase (Table 2). This suggests soil type will have an important effect on pasture $\mathrm{Na}$ increases to applied salt.

\section{Sodium in soil}

Applying $\mathrm{NaCl}$ increased soil $\mathrm{Na}$ concentrations $(\mathrm{O}-8 \mathrm{~cm})$ on all sites and, as with the pasture $\mathrm{Na}$, reached a peak 6 weeks after application and gradually declined thereafter (Table 3). After 30 weeks, however, soil $\mathrm{Na}$ levels were still approximately twice the initial values. Again there was a strong relationship between soil $\mathrm{Na}$ and rate of $\mathrm{NaCl}$ applied. Depth sampling to $30 \mathrm{~cm}$ on the 400 $\mathrm{NaCl} / 140 \mathrm{KCl}$ plots indicated definite leaching of $\mathrm{Na}$ through the profile (Table 4).

Table 3: Effect of applied $\mathrm{NaCl}$ on the soil $\mathrm{Na}$ levels

\begin{tabular}{|c|c|c|c|c|c|c|c|c|c|c|c|c|}
\hline \multirow{2}{*}{$\begin{array}{l}\mathrm{Kg} \mathrm{NaCl} / \mathrm{ha} \\
\text { Soil group }\end{array}$} & \multicolumn{3}{|c|}{50} & \multicolumn{3}{|c|}{100} & \multicolumn{3}{|c|}{200} & \multicolumn{3}{|c|}{400} \\
\hline & YBP & YBL & Peat & YBP & YBL & Peat & YBP & YBL & Peat & YBP & YBL & Peat \\
\hline $\begin{array}{l}\text { At start } \\
\text { (Sept '87) }\end{array}$ & $5^{\prime}$ & 5 & 6 & 5 & 5 & 8 & 5 & 5 & 8 & 5 & 5 & 8 \\
\hline $\begin{array}{l}6 \text { weeks } \\
\text { (Oct '87) }\end{array}$ & 8 & 9 & 17 & 15 & 12 & 22 & 16 & 16 & 27 & 24 & 24 & 40 \\
\hline $\begin{array}{l}30 \text { weeks } \\
\text { (March '68) }\end{array}$ & 7 & 7 & 14 & 8 & 6 & 18 & 9 & 9 & 22 & 13 & 12 & 32 \\
\hline
\end{tabular}

- $\mathrm{Na}$ (mg// Of extract) MAF Quick Test

Table 4: Changes in soil $\mathrm{Na}$ levels at 3 deoths on the $400 \mathrm{NaCl} / 140 \mathrm{KCl}$ treatment

\begin{tabular}{lcccc}
\hline Period & $\begin{array}{c}\text { Depth } \\
(\mathbf{c m})\end{array}$ & YBP & $\begin{array}{c}\text { Soil group } \\
\text { YBL }\end{array}$ & Peat \\
\hline At star-1 & $0-8$ & 5 & 5 & 9 \\
& $8-15$ & 3 & 3 & 8 \\
& $15-30$ & 4 & 2 & 8 \\
6 weeks & $0-8$ & 25 & 23 & 32 \\
& $\mathbf{8 - 1 5}$ & 11 & 7 & 9 \\
& $15-30$ & 9 & 8 & 33 \\
30 weeks & & 13 & 11 & 24 \\
& $0-6$ & 9 & 13 & 12 \\
\hline
\end{tabular}

* Na (mg/l of extract) MAF Quick Test

\section{Effect of $\mathrm{NaCl}$ plus $\mathrm{KCl}$ application on $\mathrm{Na}$ levels in the pasture}

Initial soil K Quick tests were medium-high on all sites (range 6-12) and plant K levels high to very high (range 3.6-4.3\%K). Such levels are typical of many Waikato and North Island dairy farms. The addition of $140 \mathrm{~kg} \mathrm{KCl} / \mathrm{ha}$ with $\mathrm{NaCl}$ in these situations had only a minimal effect on the plant $\mathrm{Na}$ levels, reducing them by 10 $15 \%$ compared with no $\mathrm{KCl}$ addition. Other evidence suggests the addition of $\mathrm{KCl}$ will have a more detrimental effect on the $\mathrm{Na}$ pasture levels where initial $\mathrm{K}$ is lower (McNaught 8 Karlovsky 1964).

\section{Recovery of applied $\mathrm{Na}$}

The percentage of applied $\mathrm{Na}$ recovered in soil and pasture (after 30 weeks) was $40 \%, 64 \%$ and $71 \%$ on sites 1,2 and 3 respectively. If allowance is made for $\mathrm{Na}$ contribution from rainfall $(15-25 \mathrm{~kg} \mathrm{Na})$ these figures are reduced to 21,36 and $62 \%$ respectively. Actual recovery in the pasture was $14 \%, 19 \%$ and $9 \%$ for sites 1,2 and 
3 respectively. Such figures do not differ greatly from those for other applied nutrients, for example Mg (O'Connor et a/. 1981).

Variations in pasture $\mathrm{Na}$ concentrations

The $\mathrm{Na}$ content of pasture on the control (no $\mathrm{NaCl}$ ) plots fluctuated widely over the 30-week sampling period (Table 5). Only some of the variation could be explained by seasonal and sample contamination. The analytical error was checked and found to be low. The data therefore suggest a 40-100\% fluctuation in pasture $\mathrm{Na}$ concentrations is possible in trial situations. As it is likely that paddock sampling for advisory purposes will give even greater fluctuations in $\mathrm{Na}$ concentrations of pasture, this must be considered when making recommendations on the use of $\mathrm{Na}$

Table 5: Variations in the $\mathrm{Na}$ concentrations of pasture on Control (no $\mathrm{NaCl}$ ) plots over 30 weeks

\begin{tabular}{rlcl}
\hline Date & YSP & $\begin{array}{c}\text { Soil group } \\
\text { YBL } \\
\text { \% Na OM basis }\end{array}$ & Peat \\
\hline 2667 & 010 & 0.14 & 0.06 \\
1310.87 & 0.12 & 0.18 & 0.09 \\
24.11 .67 & 009 & 0.11 & 0.07 \\
19.1 .88 & 013 & 0.13 & 0.11 \\
29.3 .88 & 0.13 & 0.21 & 0.12 \\
\hline
\end{tabular}

\section{DISCUSSION}

Field trial results suggest $\mathrm{NaCl}$ applied to pasture will rapidly increase the $\mathrm{Na}$ content of the pasture, reaching a peak about 6 weeks after application. The response lasts for at least 30 weeks but at a diminishing level. Even so, the pasture $\mathrm{Na}$ concentration associated with, for example, the $100 \mathrm{~kg} \mathrm{NaCl} /$ ha rate after 30 weeks was still well above the level needed to prevent $\mathrm{Na}$ deficiency in stock and some 2-3 times greater than the initial $\mathrm{Na}$ level (Table 2). It is concuded that an annual topdressing of $\mathrm{NaCl}$ at $100 \mathrm{~kg} / \mathrm{ha}$ will provide an adequate $\mathrm{Na}$ status in the pasture for animal health and production on a range of Waikato soils. There may be scope for reducing this input on some soils.

In practice salt can be applied directly to pasture or mixed in with phosphate fertilisers. Where pasture levels of $\mathrm{K}$ are already high, as on most dairy pastures, some replacement of $\mathrm{NaCl}$ for $\mathrm{KCl}$ in the fertiliser mixture could be considered. For example, a $30 \%$ potash superphosphate could become a $20 \%$ salt $10 \%$ potash superphosphate. Present results suggest uptake of $\mathrm{Na}$ in pastures already high in $\mathrm{K}$ is affected only marginally by added $K$ in fertiliser. On pastures lower in $K_{1}$ for example many sheep/beef pastures, adding $\mathrm{KCl}$ with $\mathrm{NaCl}$ could reduce $\mathrm{Na}$ uptake (McNaught \& Karlovsky 1964). In such cases a salt only or salt/phosphate fertiliser mixture is recommended. Soil and pasture $\mathrm{Na}$ should be monitored annually. Care should also be taken in grazing Na-treated pastures with pregnant cows as quite moderate increases in $\mathrm{Na}$ intake can depress plasma $\mathrm{Mg}$ levels and thereby increase the risk of hypomagnesaemic grass tetany (Smith et al. 1983). A Mg supplmentation programme for the cows should be implemented.

This study demonstrates that the $\mathrm{Na}$ content of pasture can be increased by salt applications. However animal production responses to improved pasture $\mathrm{Na}$ status have yet to be conclusively demonstrated.

\section{References}

Ames P.D., Smith S.E 1957. Sodium versus chloride for the therapy of salt deficient dairy cows. Joumal of dainy science 40: 682.688.

Babcock S.M 1905. The addition of Salt to the ration of dairy cow?. 22nd Annual Report University of Wisconsin Agricultural Experiment Station. 129-56 
Carruthers, V.T.; O'Connor, MB.; Feyter, C.; Upsdell, M.P.; Ledgard. SF. 1987. Results from the Ruakura bloat Survey. Proceedings Ruakura Farmers' Conference 39: 44-46.

McNaught KJ.; Karlovsky J. 1964. Sodium chloride responses in pasture on a potassium-deficient soil. NZ journal of agricutural research 7: 386-404.

O'Connor, M.B.; Feyter, C. Young P.W. 1981. Topdressing pastures with Mg fertiliser and its effect on subclinical hypomagnesaemia in dairy cows. Proceedings 18th Technical Conference. NZ Fertiliser Manufacturers Research Association V2: 335-42.

Smith, G.S.; Young, P.W.; O'Connor. M.B. 1983. Some effects of topdressing pasture with sodium chloride on plant and animal nutrition. Proceedings NZ Grassland Association 44: 179-185.

Towers N.R.; Smith, G,S. 1983. Sodium (Na). pp. 115.24. In The mineral requirements of grazing ruminants. NZ Society of Animal Production Occasional Publication No. 9. 